\title{
Obituaries
}

\section{Jordi Casals-Ariet}

\author{
Epidemiologist who discovered the Lassa fever virus-and nearly died from it
}

Jordi Casals-Ariet, an epidemiologist and virologist, was hailed by scientists around the world when he discovered the virus that causes Lassa fever. He was nearly killed by the disease in 1969 while working with the virus in his Yale laboratory. In a high-stakes gamble and with no known treatment, his doctors decided to transfuse him with blood from a nurse who had survived Lassa fever. The blood saved his life.

But colleagues say that Dr Casals' contributions are far greater than his discovery of the Lassa fever virus. "He did a yeoman's work in establishing useful methods of classifying viruses," said Dr Gregory Tignor, professor emeritus at Yale, who worked with Dr Casals.

Little was known about many viruses when Dr Casals started his work at Yale. "Everybody has forgotten how bad it was back then," said Dr Tignor. "People didn't know what was causing encephalitis. We had no way of telling the difference between rabies encephalitis, polio encephalitis, or other causes of encephalitis. But Jordi found ways, using antigens and antibodies, to figure it out. His work was so meticulous that to this day nobody has changed his classifications because they have all held up."

Charles H Calisher, professor of microbiology at Colorado State University, said that Dr Casals defined the field of viral taxonomy for thousands of viruses that affected humans, livestock, plants, and bacteria. He served on many scientific com-

\section{Advice}

We will be pleased to receive obituary notices of around 250 words. Pressure on space means that in most cases we will be able to publish only about 100 words in the printed journal, but we can run a fuller version on our website. We will take responsibility for shortening. We do not send proofs. Good quality, original photographs are welcome. Please give a contact telephone number and, where possible, supply the obituary on a disk or byemail to obituaries@bmj.com

We need to know the year of birth and exact date of death of the deceased, and we prefer obituaries to state the cause of death. Please spell out abbreviations.

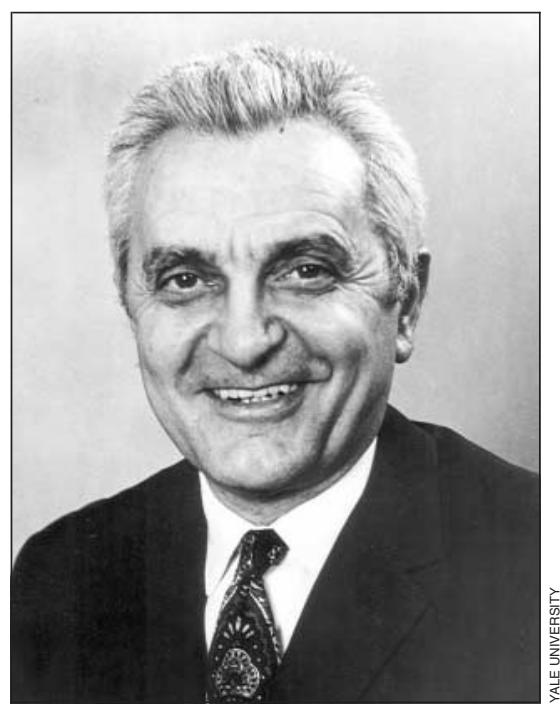

missions on polio, and mosquito and tick-borne viruses, and worked with scientists in Japan on the Japanese encephalitis virus and the former Soviet Union on haemorrhagic fever viruses.

Jordi Casals-Ariet was born in Viladrau, Girona, Spain, in 1911. He came to the United States after graduating from medical school in Barcelona. He joined the Rockefeller Institute for Medical Research in 1936 after two years in the department of pathology at Cornell University Medical College. When his unit at the Rockefeller Institute moved to Yale in 1964, Dr Casals transferred with the unit and remained there until his retirement in 1981.

That Dr Casals' work has held up over time is something his wife, Ellen Evelyn Casals-Ariet, says was due to his refusal to accept a single test result as proof of anything. "He'd repeat a successful test over and over and over again," said Ms CasalsAriet. "Jordi was disturbed by people who didn't repeat tests. Now we see just one test being used to promote something. What's good one day is bad the next. It causes the public to despair. Jordi was upset by researchers who didn't repeat their tests. He said they were too anxious to get published or be first with a discovery."
Several close colleagues of Dr Casals said his professional ethics impressed them as much as his scientific methods. "People who worked in that day and age worked at great risk to themselves personally. Many investigators died from yellow fever and some from polio. But they did it because of the benefit for mankind," said Dr Tignor. "Today, our research is centered on what's going on in America and to hell with the rest of the world. If you want to study a disease you have to study diseases of rich old white men because they are the ones who sit in Congress. But Jordi studied diseases that affected people who were dying in Africa."

Ms Casals-Ariet said that in later years "Jordi complained that non-commercial funding was harder and harder to find. It was a constant problem. That's why he liked working for the Rockefeller Institute. They were free to pursue science for the sake of science and not because some big corporation could make money from it."

Dr Casals served as a consultant to the Walter Reed Army Institute of Research, the World Health Organization, the US National Institutes of Health, and the International Committee on Taxonomy of Viruses. In 1969 he received the Richard M Taylor Award, given by the American Committee on Arthropod-Borne Viruses once every three years to "a person who has made outstanding contributions to arbovirology throughout his or her career." He also received the Kimble Methodology Award from the American Public Health Association.

Ms Casals-Ariet said that when people heard her name they would often say, "Casals? Casals! Are you related to Pablo Casals [the cellist]?" But one day, to her great pleasure, a visiting doctor from Europe, exclaimed, "Casals? Casals! Are you related to Jordi Casals?"

He leaves a wife, Evelyn "Lyn," and a daughter. [JEANNE LENZER]

Jordi Casals-Ariet, virologist and epidemiologist Yale University, New Haven, Connecticut, United States (b Viladrau, Spain, 1911; q University of Barcelona 1934), d 10 February 2004.

Longer versions of these obituaries are available on bmj.com 


\section{Terrence Noel Joseph Alles}

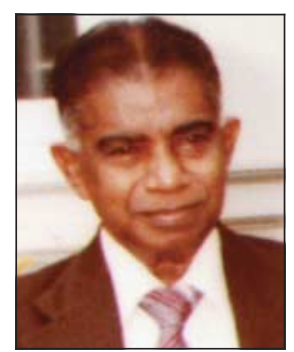

Former senior medical officer Ratnam's Private Hospital, Colombo, Sri Lanka (b Colombo 1920; q Colombo Medical College 1947), died from a stroke on 24 October 2003.

Terry did a brief spell in the Government Hospital in Mannar and joined Ratnam's Private Hospital, Colombo, where he continued for 55 years. Like his father, Terry was attendant physician to the archbishop of Colombo. A devout Catholic, Terry took a keen interest in his garden and had a passion for old cars. He leaves a wife, Rita; two children; and four grandchildren. [REMY Perumal]

\section{Nachman Ambache}

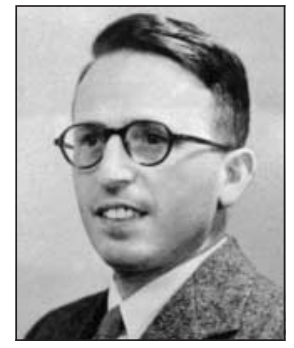

Former researcher in physiology and pharmacology Medical Research Council (b Egypt 1917; q Cambridge/Oxford 1943), died from heart failure on 3 February 2004. From 1943 to 1946 Nachman Ambache became demonstrator and assistant lecturer in pathology and bacteriology at Guy's Hospital Medical School and in 1947 he became lecturer in physiology at University College London. Settling on a career in physiology and pharmacology in 1948, he joined the full time staff at the Medical Research Council ophthalmologic research unit, and later the MRC external staff at the Royal College of Surgeons, being promoted to special appointments grade. In 1957 his researches into prostaglandins led him into the discovery of irin. He was an accomplished violinist. He leaves a wife and two children. [DEsmond Greaves]

\section{Samuel Henry Brock}

Former director of public health Calderdale Health Authority (b Devonport 1935; $q$ Edinburgh 1959; DPH), died from a ruptured abdominal aortic aneurysm on 9 August 2003. Sam's experience of organising community clinical and environmental health services

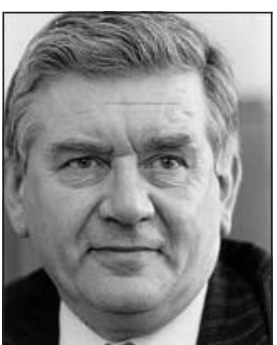

matured in posts in Fife, Yorkshire, and finally Calderdale. He survived three reorganisations of the NHS. In the major 1974 reorganisation he became area medical officer to the new Calderdale Health Authority and remained in that role, with different titles, retiring at the 1993 reorganisation and the authority's demise. He saw and presided over many technological and organisational changes in primary and secondary care, and strove to develop links with local communities so that the organisation was not remote from them. He leaves a wife, Margaret, and two children. [HowARD BARNES, Brian Williams]

\section{David Sydney Gordon}

Former emergency physician (b Hampshire 1943; q Edinburgh 1967; DObst RCOG), d 14 March 2003.

David entered general practice in Ludlow in 1973. He served as surgeon lieutenant commander with the Royal Naval Volunteer Reserve between 1965 and 1978. In 1983 David became medical officer with the Royal Fleet Auxiliary, but his seafaring days ended when he developed polyarteritis nodosa subsequently undergoing bilateral nephrectomies. After a successful renal transplant in 1987 David returned to work, this time in accident and emergency departments in Hereford, Bromsgrove, Stockport, and Wolverhampton. He leaves a wife, two children, two stepchildren, and one grandson. [P E GoRDon]

\section{Robert ("Robin") Anthony Kell}

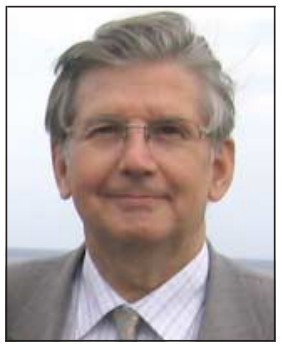

Consultant ear, nose, and throat surgeon Victoria Infirmary and Southern General Hospital, Glasgow, 1972-2003, and consultant ENT surgeon Royal Alexandra Hospital, Paisley, 1972-1984 (b Bishop Auckland, County Durham, 1939; $q$ St Andrews 1963), died from metastatic prostate cancer on 17 December 2003.

Robin was appointed as a consultant ear, nose, and throat surgeon in Glasgow in 1972.
He served on council for the Royal College of Physicians and Surgeons of Glasgow, was president of the Scottish ENT society and examiner for the intercollegiate board, and was the clinical director for ENT in the Victoria Infirmary and Southern General Hospital for many years. Robin played the piano expertly and also enjoyed playing the fiddle. He leaves a wife, Babs; three children; and two granddaughters. [MALCOLM KeLL, SANDY CoOPER, JAMES Mowat]

\section{George Alexander Mogey}

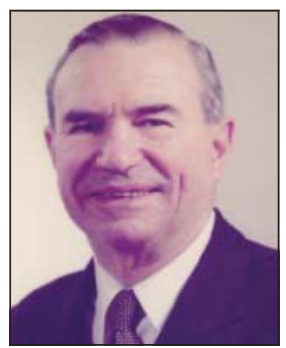

Former secretary to the Council for Postgraduate Medical and Dental Education in England and Wales (b Ballymoney, County Antrim, 1917; $q$ Belfast 1940; MD), died from Parkinson's disease on 13 December 2003.

George Mogey had a lifelong commitment to medical education. After graduation he served with the Royal Army Medical Corps in west Africa and India. In 1946 he became a research assistant in pharmacology at Wellcome, moving to Leeds in 1951 as a lecturer and then senior lecturer. $\mathrm{He}$ was seconded in 1962-3 to the Pakistan Council of Scientific and Industrial Research to establish a drug research laboratory. Following five years as regional director of postgraduate medical education in Newcastle he was appointed secretary to the Council for Postgraduate Medical and Dental Education in England and Wales in 1976. He leaves a wife, Audrey; three daughters; and five grandchildren. [JOHN L DUNCAN]

\section{Bernard ("Bernie") John O'Brien}

Director of the programme for assessment of technology in health and professor, department of clinical epidemiology and biostatistics, McMaster University, Ontario, Canada (b Birmingham 1959; PhD), died while jogging on 13 February 2004.

Bernie trained in health economics at York and Brunel and became a member of the research team looking at costs and benefits of the embryonic heart transplant programmes at Harefield and Papworth hospitals. In 1990 he moved to McMaster University, where he carried out research on economic evaluation of health technologies. His group had recently begun working on a programme of health technology assessment and economic evaluation for the Ontario Ministry of Health. He leaves a wife, Karen, and two daughters. [MARTin Buxton] 